\title{
Roll-Type Optical Advanced Memory with High Recording Capacity
}

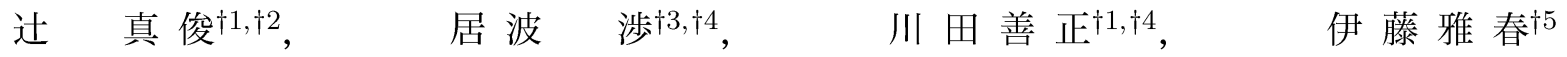

Masatoshi Tsuji ${ }^{11, \uparrow 2}$, Wataru Inami ${ }^{\dagger 3, \uparrow 4}$, Yoshimasa Kawata ${ }^{\dagger 1, \uparrow 4}$ and Masaharu Ito $^{\dagger 5}$

\begin{abstract}
We propose a newly developed roll-type optical memory (RoCAM). This memory is a multilayered memory and has a cylindrical shape. It consists of a recording and transparent layers wound onto a shaft. A RoCAM has five advantages. First, the media is easily fabricated. Second, the groove structures in RoCAM are easily implemented. Third, it has parallel recording and reading. Fourth, there is stable rotation and, finally, constant linear velocity. We report these advantageous features and the one-dimensional parallel signal readout of RoCAM.
\end{abstract}

キーワード : 多層光メモリー，ロール型記録媒体，共焦点顕微鏡

\section{1. ま え がき}

2010 年に 3 層 100 GBの Blu-ray disc が規格化され，光 メモリーの大容量化が進んでいる. 光メモリーの記録容量を 1 TB 以上まで増加させるため, 現在多くの手法が提案され 研究が進められている。代表的なものには，ホログラフィッ クメモリー ${ }^{12)}$, ソリッドイマージョンレンズ (SIL) を用 いた近接場メモリー ${ }^{3)}$, 超解像近接場構造 (Super-RENS) 方式 ${ }^{4)}$ ，多層光メモリー5) などがある.

多層光メモリーは大容量化に向けた有望な手法の一つで ある。近年にはパイオニアの小笠原氏，TDK の菊川氏よ り, 現存の Blu-ray disc を拡張し 512 GB もの容量を持 つ多層光メモリーが報告されている ${ }^{6)}$ ，そのほか表面プラ

2011 年 1 月 21 日, マルチメディアストレージ, コンシューマエレクトロ ニクス研究会で発表

2011 年 5 月 26 日受付, 2011 年 9 月 21 日採録

$\dagger 1$ 静岡大学 工学部

（浜松市中区城北 3-5-1，TEL053-478-1069）

$\dagger 2$ 日本学術振興会 特別研究員

(千代田区一番町 8 番地, TEL03-3263-5070)

$\dagger 3$ 静岡大学 若手グローバル研究リーダー育成拠点

（浜松市中区城北 3-5-1，TEL053-478-1371）

$\uparrow 4$ JST-CREST

(千代田区 三番町 5 番地, TEL03-3512-3531)

†5 リンテック株式会社 研究所 デバイス材料研究室

(埼玉県蒴市錦町 5-14-42，TEL048-430-1708)

$\dagger 1$ Faculty of Engineering, Shizuoka University

(3-5-1, Naka-ku, Johoku, Hamamatsu)

$\dagger 2$ Research Fellow of the Japan Society for the Promotion of Science (1-8, Chiyoda-ku, Tokyo)

$\dagger 3$ Division of Global Research Leaders, Shizuoka University (3-5-1, Naka-ku, Johoku, Hamamatsu)

$\dagger 4$ JST-CREST

(3-5, Chiyoda-ku, Tokyo)

†5 Device Materials Laboratory, Research Center, LINTEC Corporation

(5-14-42, Nishiki, Warabi, Saitama)
ズモンを導入した多層光メモリーの報告もなされている77. オーストラリアSwinburne 工科大学の Gu 氏は, 多層光メ モリーに偏光多重記録，波長多重記録を導入した 5 次元光 メモリーを提案している ${ }^{8}$.

我々は以前より多層光メモリーの研究を行ってきた ${ }^{9) 10)}$. 多層メディアは粘着剤を用いたラミネート法により作製し た ${ }^{11)}$ 。この方法ではまず，記録層と粘着剤で構成したシー トを準備する，その後シートを 1 枚ずつ基板上に積層する ことで多層構造を作製する，この方法の利点は，記録層，粘 着剤の厚さが均一になることであるが，積層するために複 数回作業工程を有する.

多層構造を容易に作製するため，ロール型メモリーを開発 した。我々はこのメモリーを Roll-type optical advanced memory (RoCAM) と名付けた。この報告で我々は RoCAMについて紹介する.

\section{RoCAM の特徵}

図 1 に RoCAM の概念図を示す，RoCAM は円筒形状を 持つ多層光メモリーである．RoCAM の記録は，レーザー 光を RoCAM の側面から入射して行う. 再生時も同様に レーザー光を側面から入射し，反射信号を検出する．検出 器前方にピンホールを配置することで, 共焦点顕微光学系 を構成することもできる。

ロール形状にすることで大きく五つの利点が生まれる。 次節から RoCAM の利点について述べる.

\section{1 メディア作製が容易}

RoCAM の最も大きな利点は, 多層メディアの作製が容 易になることである．図 2 に RoCAM の作製方法を示す. 記録層，粘着剤で構成された 1 枚のシートを，芯棒となる シャフトに巻きつけるだけで多層構造を作製できる。また 


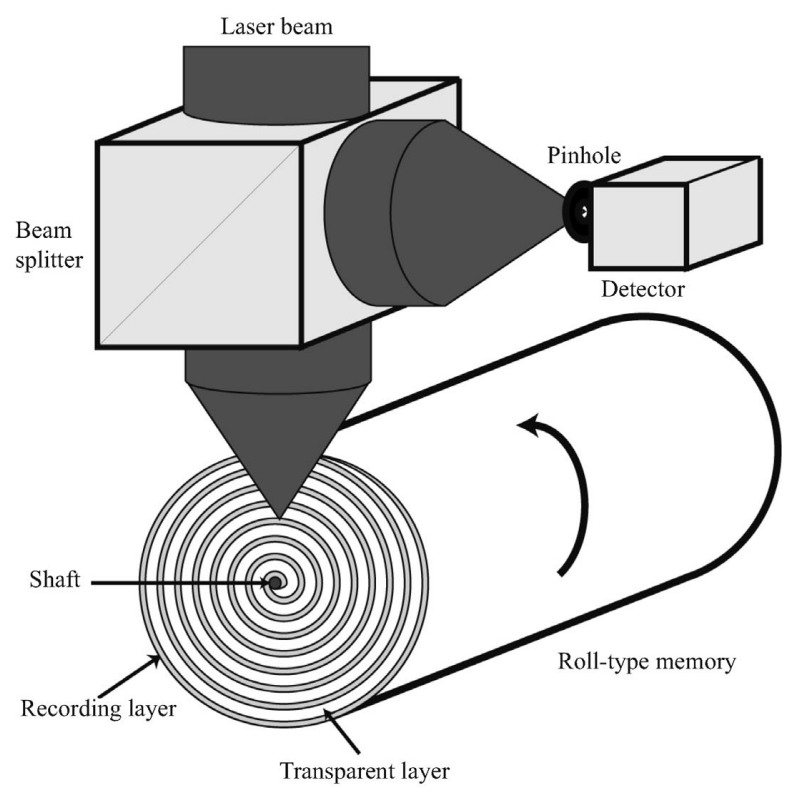

図 1 RoCAM の概念 Concept of RoCAM.

表 1 RoCAM とディスクメディアとの比較 Comparing with RoCAM and disc media.

\begin{tabular}{c|c|c|c|c}
\hline \hline \multicolumn{2}{l|}{} & 1層の面積 & $\begin{array}{c}\text { 同じ記録容量を } \\
\text { 満たすための層数 }\end{array}$ & $\begin{array}{c}\text { 1 TBを実現する } \\
\text { ための層数 }\end{array}$ \\
\hline \multirow{2}{*}{ RoCAM } & AA & $23.0 \mathrm{~cm}^{2}$ & 4層 & 160層 \\
\cline { 2 - 5 } & AAA & $14.7 \mathrm{~cm}^{2}$ & 6層 & 240層 \\
\hline \multicolumn{2}{c|}{$\mathrm{BD}$} & $86.0 \mathrm{~cm}^{2}$ & 1層 & 40 層 \\
\hline
\end{tabular}

巻きつけ回数を変化させるだけで, 記録容量の異なるメディ アも作製できる，我々はRoCAM のサイズを乾電池程度に 想定している。

RoCAM の 1 層あたりの記録容量を，ディスクメディア の場合と比較する。表 1 は, RoCAM を単 3 乾電池サイズ と単 4 乾電池サイズとして仮定した場合の, デイスクとの記 録容量の比較である. 表 1 では, 単 3 乾電池を $\mathrm{AA}$, 単 4 乾 電池を AAA と表記した. RoCAMが AA と同サイズの場 合, メディアの直径は $14.5 \mathrm{~mm}$, 長さは $50.5 \mathrm{~mm}$ となる. 同様に AAA の場合では, 直径 $10.5 \mathrm{~mm}$, 長さは $44.5 \mathrm{~mm}$ となる。 上記の值から $\mathrm{AA}$ の表面積は $23 \mathrm{~cm}^{2}, \mathrm{AAA}$ では $14.7 \mathrm{~cm}^{2}$ となる. ディスクメディアの場合, 記録層の面積 は $86 \mathrm{~cm}^{2}$ である. よって AA サイズの RoCAM の場合, 4 層のメディアを作製するとディスク 1 枚分と同じ記録容 量が得られる。同様に AAA の場合では 6 層となる.

記録容量 1 TB を実現するには, Blu-ray discでは 40 層, $\mathrm{AA}$ は 160 層, $\mathrm{AAA}$ は 240 層となる。 160 層の RoCAM を記録層厚さ $1 \mu \mathrm{m}$, 記録層間隔 $5 \mu \mathrm{m}$ で作製すると, 厚さ が $0.8 \mathrm{~mm}$ にしかならない. ロール形状の記録媒体のほと んどが芯であり，その表面 $1 \mathrm{~mm}$ 弱だけが記録領域となる.

\section{2 グルーブの転写が容易}

ディスク形状の多層光メモリーは, 各層の厚さが数 $\mu \mathrm{m}$ と薄い. そのためディスク形状の多層光メモリーでは, 久 タンパーを用いてグルーブを転写することが困難となる.

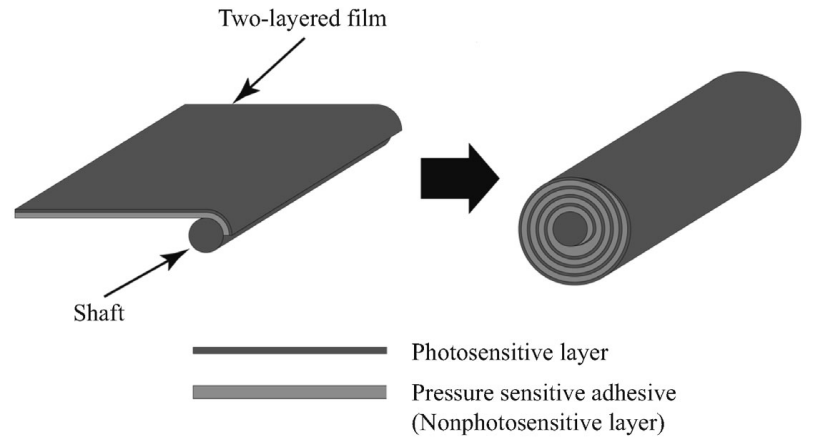

図 2 RoCAM の作製方法 Fabrication procedure of RoCAM.

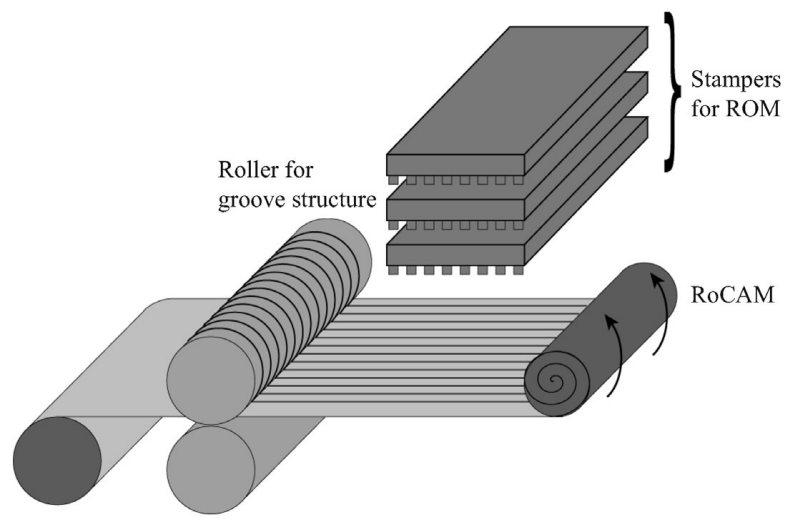

図 3 RoCAM のグルーブ転写方法 Imprint of groove structure in RoCAM.

RoCAM の場合，多層構造を作製すると同時にグルーブを 転写できる. 図 3 に RoCAM のグルーブ転写方法を示す. RoCAM は 1 枚のシートで多層構造を作製しているため, シャフトに巻きつける途中に円筒形状のスタンパを用いて 転写できる。この技術は，ROM を作製への応用も期待で きる。

\section{3 並列記録や並列再生が可能}

RoCAM は 1 次元並列記録・再生が可能である. 図 4 に 1 次元並列記録, 並列再生の光学系を示す. 1 次元並列記 録と再生は, レーザー光をライン状に変換し, シリンドリ カルレンズを用いてライン状にメディア内に集光すること で実現できる。再生時には，1 次元 CCD カメラを用いて 複数の信号を一度に検出する. そのため現存の光ディスク より転送レートを大幅に向上させることができる．1 次元 CCD カメラ前方にはスリットを配置する.メディア内集光 位置と 1 次元 $\mathrm{CCD}$ カメラ上集光位置が共役な関係となる ため, ライン状共焦点顕微光学系となり, 本システムは光 軸分解能を有している.

\section{4 回転の安定性}

RoCAM は回転時の面ブレが小さいことが挙げられる. 既存のディスクは中心を支持され回転している，回転時に デイスクの淵は大きく振動するため, デー夕を読出すため にフォーカスサーボ技術が採用されている。一方 RoCAM ではシャフトを双方向から支持する。そのため既存のディ 


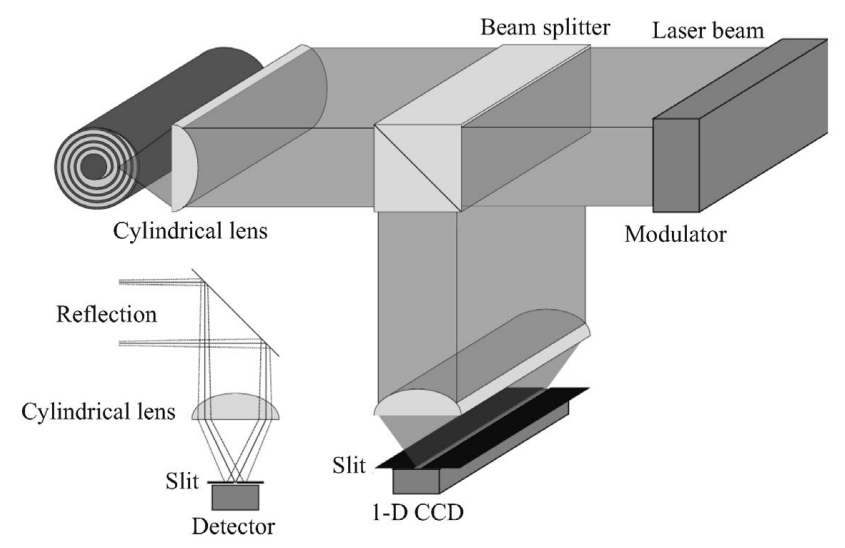

図 4 RoCAM $の 1$ 次元並列記録, 並列再生

One-dimensional parallel recording and reading of RoCAM.

スクと比較して，メディアの面ブレを低減させることがで きる。

\section{5 同じ回転速度で線速度が一定}

RoCAM は線速度が一定となる. 既存のディスクではデー 夕の再生時に, ディスク中心から外周部へ読み出していく につれて回転速度を変化させている。この理由は, ディス クの内外で同一線速度にし, デー夕転送速度を一定にする ためである。一方 RoCAM では, シャフトからメディア表 面に向かって記録・再生を行う場合, 回転速度を変化させ る必要がほとんどない。これは, RoCAM は多層に積層し た場合でもメディア直径がほとんど変化しないためである. よって RoCAM の回転速度の制御は, ディスクのものと比 較して容易になる。

\section{RoCAM の 1 次元並列再生}

既存のスタンパを用いてグルーブを転写した RoCAM の, 静的な 1 次元並列再生の検証を行った. 図 5 に 1 次元並列再 生のための光学系を示す．再生光源には波長 $633 \mathrm{~nm}$ のへ リウムネオンレーザーを使用した。 ビームはシリンドリカ ルレンズを用いてライン状に変換した。 ライン状ビームは 対物レンズの瞳面に集光した. 対物レンズ後は, $\mathrm{X}$ 軸方向に はライン状に RoCAM に照射し, Y 軸方向には集光される. RoCAM からの反射光は, ビームスプリッタで分岐され, 1 次元 CCD カメラに結像させた。本手法では, RoCAM か らの多くの回折光は対物レンズで取り込まれ, 画像として 1 次元 CCD カメラで検出される. スリットは 1 次元 CCD カメラ前方に配置した。 RoCAMの集光位置とスリット位 置が共役な関係になるため, 本光学系はライン状共焦点顕 微光学系となる。使用した対物レンズは開口数 (NA)1.3の 油浸対物レンズ，スリット幅は $30 \mu \mathrm{m}$ であった。

1 次元並列再生を行うため, グルーブを持つ RoCAM を 作製した. 図 6 は作製した RoCAM の構成を示す.グルー ブは DVD の円形のスタンパを用いて, 紫外線硬化フィル ムと粘着剤の界面に転写した。その後グルーブを持つ UV

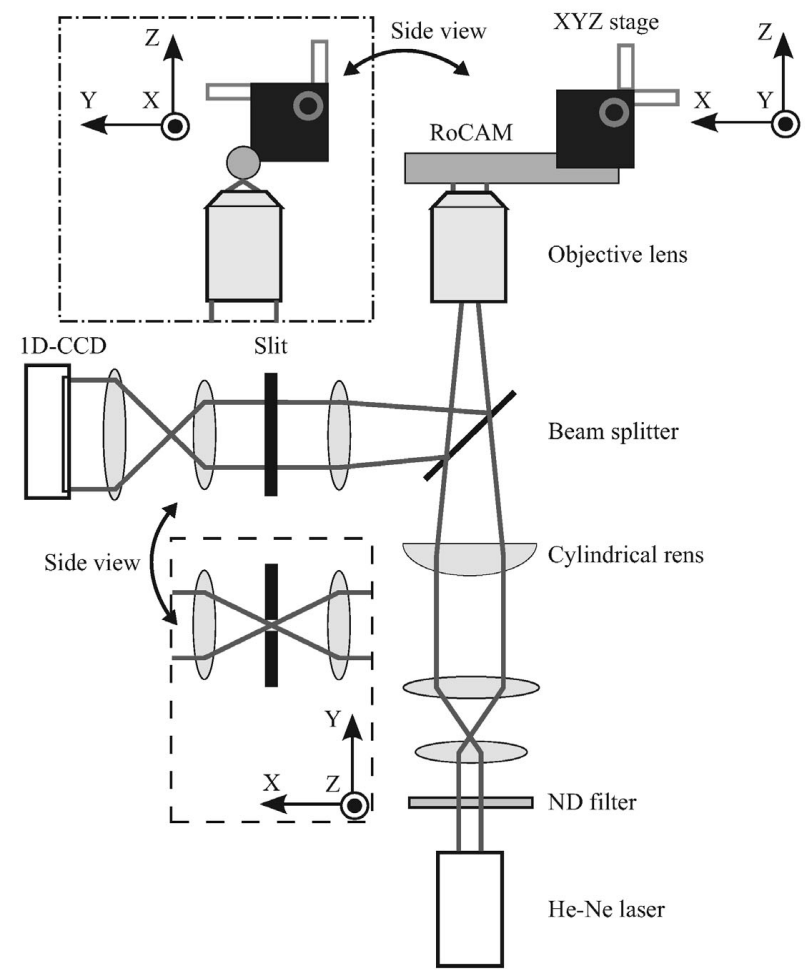

図 5 RoCAM の 1 次元並列再生光学系 Optical setup for one-dimensional parallel readout of RoCAM.

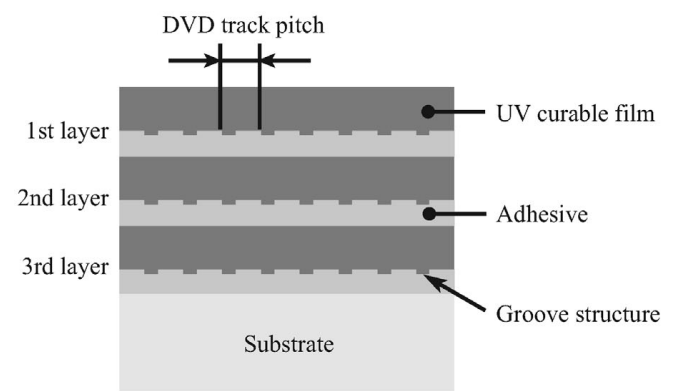

図 6 グルーブを持つ RoCAM の構成 Composition of groove-structured RoCAM.

硬化フィルムは, 1 枚の長方形のシートとして切り出され, シャフトに巻きつけ多層構造を作製した。 今回層数 3 層の RoCAM を作製した。紫外線硬化フィルムと粘着剤の厚さ はそれぞれ $25 \mu \mathrm{m}, 10 \mu \mathrm{m}$, 屈折率はそれぞれ 1.51, 1.47 であった。

グルーブがUV 硬化フィルム上に転写されているか確認 するため，共焦点顕微鏡を用いて層界面を観察した。図 7 はグルーブを転写した界面の共焦点顕微鏡画像である。挿 入図は四角部の拡大図である. 図 7 より, 垂直方向にグルー ブが転写されていることがわかる。このことから RoCAM の層界面にグルーブを転写できていることを確認できた.

図 8 はグルーブを持つ RoCAM の多層再生結果を示して いる。図 8(a) は 1 層目界面からの信号, 図 8(b) は 2 層目 界面からの信号, 図 $8(\mathrm{c})$ は 3 層目界面からの信号である. ライン状にビームを照射することで, 複数の信号を一度に 検出できた。一度に検出できる信号は図 8(b)より 11 あり, 


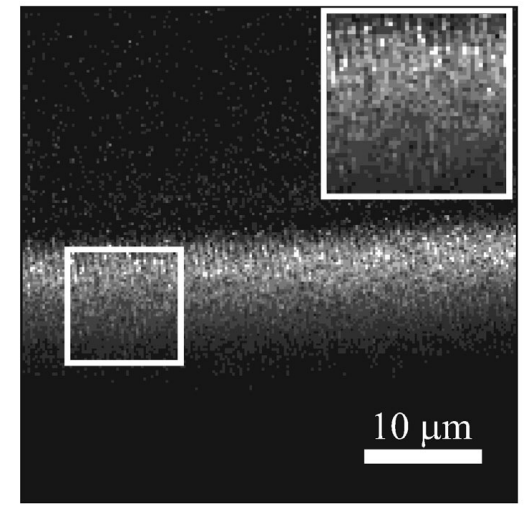

図 7 グルーブを持つ層界面の共焦点顕微鏡像：挿人図, 白線 内部の抎大図

Confocal microscopy image of groove-structured layer interface: Inset, magnified image at white square.

RoCAM のデー夕転送速度は従来のものと比較して 11 倍 向上させることができると言える. 図 8(a)-(c) で信号の周 期が異なるのは, 円形状のスタンパを用いたことが起因し ている．グルーブは円形状のスタンパを用いて転写するこ とで, シャフトの軸に対し斜め方向に存在する箇所もあり, その結果, 信号周期が変化している要因となる.

図 9 は, 1 層界面より $25 \mu \mathrm{m}$ 内部からの信号である. 図 9 から,グルーブを転写していない部分からは信号は検出 されなかった。つまり, 図8で示したグルーブからの信号 にはクロストークがなく, 各層分離して信号検出がなされ たと言える。図 8(c) の信号と図 9 の信号を比較すると, 本 メモリーの信号雑音比 (SNR) は $13 \mathrm{~dB}$ となった. また, 図 8(c)の信号の摇らぎをノイズとして扱うと, SNRは $8 \mathrm{~dB}$ となった。

\section{4. むす び}

我々は, 新しい多層光メモリーである RoCAM を提案し た。 RoCAM は大きく五つの利点を持ち，それはメディア 作製が容易, グルーブの転写が容易, 並列な記録・再生が 可能, 回転の安定性, 同じ回転速度で線速度が一定である 点が挙げられる.

RoCAM の 1 次元並列再生を行った. 1 次元並列再生を 行うため, グルーブを持つ 3 層 RoCAM を作製した. 1 次 元並列再生を行った結果, 11 のピークを一度に取得できた。 このことから, RoCAM のデータ伝送レートを従来のシス テムと比較して 11 倍向上させることができる．また，各層 クロストークなく信号を検出でき，本メモリーの SNR は $13 \mathrm{~dB}$ であった。

本研究はメディアを回転させない静的な状態で 1 次元並 列再生を行った。そこで今後は動的な状態での 1 次元並列 再生を行う。それに伴い, 各種サーボ技術を考案する。

\section{(文 献)}

1) L. Dhar, A. Hale, H. E. Katz, M. L. Schilling, M. G. Schnoes, and F. C. Schilling: "Recording Media that Exhibit High Dynamic Range for Digital Holographic Data Storage”, Opt. Lett., 24, pp.

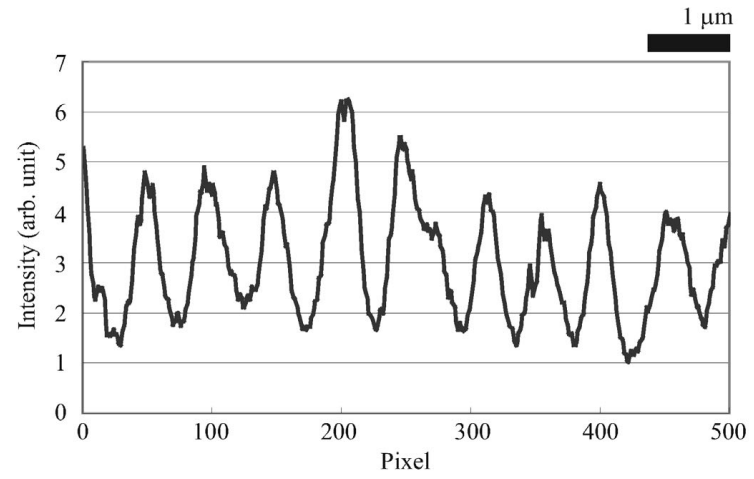

(a)

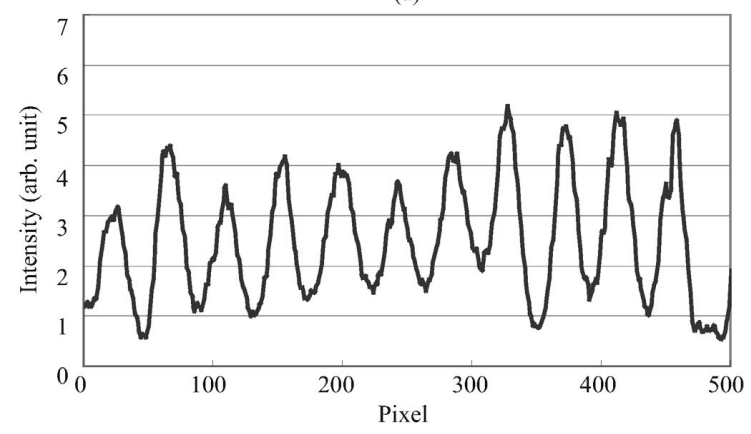

(b)

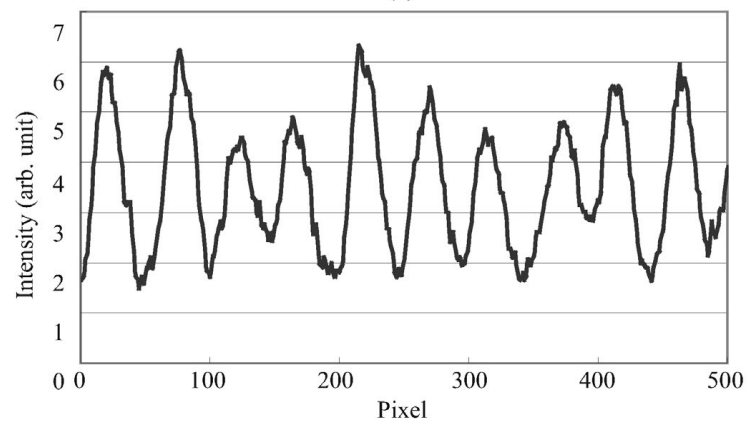

(c)

図 8 RoCAM の 1 次元並列再生結果 : (a)1 層界面からの信 号, (b)2 層界面からの信号, (c)3 層界面からの信号 One-dimensional parallel readout results of groovestructured RoCAM: (a) signals from first layer interface, (b) signals from second layer interface, (c) signals from third layer interface.

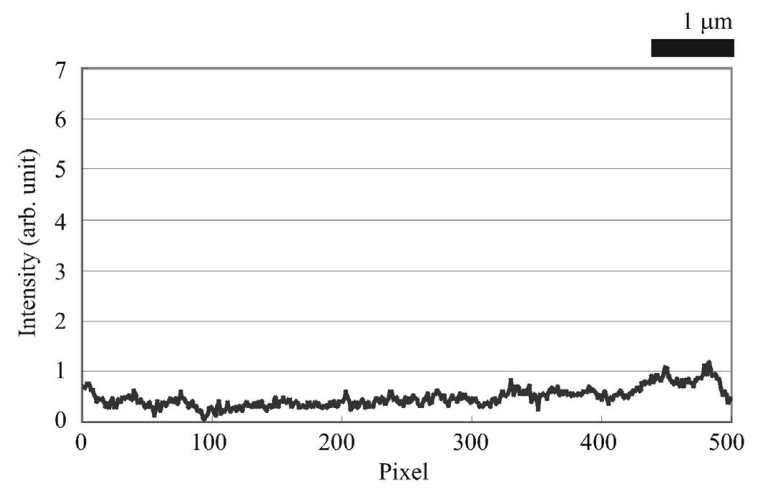

図 9 グルーブが転写されていない部分からの信号 Signals from medium without grooves.

487-489 (1999)

2) H. Horimai, X. Tan, and J. Li: “Collinear Holography, " Appl. Opt., 44, pp. 2575-2579 (2005)

3) M. Shinoda, K. Saito, T. Ishimoto, T. Ito, A. Nakaoki, M. Yamamoto, O. Maeda, T. Hashizu, T. Asano, K. Takagi, and M. 
Tazoe: “High Density Near-Field Optical Disc System”, Jpn. J. Appl. Phys., 45, pp. 1321-1324,(2006)

4) J. Tominaga, H. Fuji, A. Sato, T. Nakano, T. Fukaya, and N. Atoda: "The Near-Field Super-Resolution Properties of an Antimony Thin Film”, Jpn. J. Appl. Phys., 37, pp.L1323-L1325 (1998)

5) S. Kawata and Y. Kawata: “Three-Dimensional Optical Data Storage Using Photochromic Materials”, Chem. Rev., 100, pp. 1777-1788 (2000)

6) M. Ogasawara, K. Takahashi, M. Nakano, M. Inoue, A. Kosuda, and T. Kikukawa: “16 Layers Write Once Disc with a Separated Guide Layer”, Technical digest of ISOM' 10, pp. 224-225 (2010)

7) T. Takuo: "Plasmon Enhanced Three-Dimensional Multi-Layer Optical Disk”, Technical digest of ISOM’10, pp. 28-29 (2010)

8) P. Zijlstra, J. W. M. Chon, and M. Gu: “Five-Dimensional Optical Recording Mediated by Surface Plasmons in Gold Nanorods", nature, 459, pp. 410-413 (2009)

9) M. Nakano, T. Kooriya, T. Kuragaito, C. Egami, Y. Kawata, M. Tsuchimori, and O. Watanabe: “Three-Dimensinal Patterned Media for Ultrahigh-Density Optical Memory”, Appl. Phys. Lett., 85, pp. 176-178 (2004)

10) M. Tsuji, W. Inami, and Y. Kawata: “Alignment-Free Fiber Confocal Microscope and All-Fiber Optical System for Multilayered Optical Memories", Jpn. J. Appl. Lett., 49, pp. 08KF03 (2010)

11) M. Miyamoto, M. Nakano, M. Nakabayashi, S. Miyata, and Y. Kawata: "Fabrication of Multilayered Photochromic Memory Media Using Pressure-Sensitive Adhesives”, Appl. Opt., 45, pp. 8424-8427 (2006)

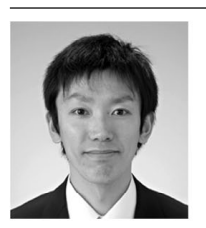

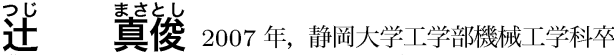
業. 2010 年, 日本学術振興会特別研究員 (DC2). 2011 年, 静岡大学創造科学技術大学院博士後期課程修了. 2011 年, 日本学術振興会特別研究員 (PD). 博士 (工学). 主 として高密度光メモリー, ファイバーレーザー, 顕微光 学, 非線形光学に関する研究に従事.

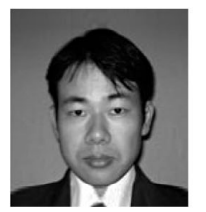

居菠㔔涉 2000 年, 日本学術振眮会特別研究員 (DC1). 2003 年, 静岡大学大学院理工学研究科博士後 期課程システム科学専攻修了. 2003 年, 日本電子株式会 社入社 2004 年, 東北大学多元物質科学研究所研究員 2009 年, 静岡大学若手グローバル研究リーダー育成拠点 特任助教. 工学博士。

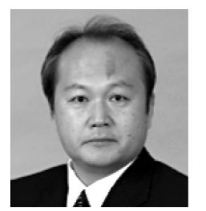

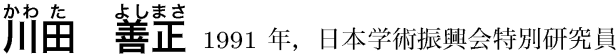
(DC2)。1992 年, 大阪大学大学院博士後期課程応用物 理学専攻修了. 1992 年, 大阪大学工学部応用物理学科助 手, 1995 年, AT\& T Bell 研究所, 1997 年, 静岡大学 工学部機械工学科助教授. 2005 年, 同教授. 工学博士.

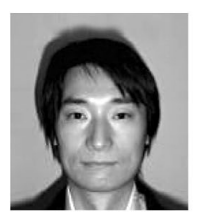

伊筝 雅春 2005 年, 大阪大学大学院工学研究科 物質生命工学専攻修了. 2005 年, リンテック株式会社入 社. 光学薄膜, 半導体加工用粘着テープの研究開発に従 事. 2007 年 4 月より，デバイス材料研究空へと移動し， 光記録媒体の研究開発に従事。 